\title{
From Mining Innovations to Sustainable Development: Keynote Speakers of the First to the Second International Innovative Mining Symposium
}

\author{
Michal Cehlár ${ }^{1}$, Juraj Janočko ${ }^{1}$, Nuray Demirel $^{2}$, Seroni Anyona ${ }^{3}$, Stefan Vöth $^{4}$, Maxim \\ Tyulenev ${ }^{5,}$, and Sergey Zhironkin ${ }^{6}$ \\ ${ }^{1}$ Technical University of Kosice, Faculty of Mining, Ecology, Process Control and Geotechnologies, \\ Letná 9, 04200 Kosice, Slovak republic \\ ${ }^{2}$ Mining Engineering Department, Middle East Technical University, Üniversiteler Mah., Dumlupınar \\ Bulvarı, No: 1, 06800 Çankaya, Ankara, Turkey \\ ${ }^{3}$ Jomo Kenyatta University of Agriculture \& Technology, Mining, Materials \& Petroleum \\ Engineering Department, P.O. Box 62000 - 00200, Nairobi, Kenya \\ ${ }^{4}$ Technische Hochschule Georg Agricola, Centre for Drive and Lifting Technology ZAFT, Bochum, \\ Germany \\ ${ }^{5}$ T.F. Gorbachev Kuzbass State Technical University, Department of Open Pit Mining, 28, \\ Vesennyaya, 650000, Kemerovo, Russia \\ ${ }^{6}$ T.F. Gorbachev Kuzbass State Technical University, Belovo Branch, 652644 Ilyicha st. 32, Inskoy, \\ Kemerovo oblast, Russia
}

\begin{abstract}
April, 2017 the Scientific Practical Conference "International Innovative Mining Symposium (in memory of Prof. Vladimir Pronoza)" was successfully organized at T.F. Gorbachev Kuzbass State Technical University - KuzSTU (Kemerovo Russia). More than 20 participants submitted their papers in presence, and more than 40 authors sent their papers for virtual participation. The main participants of the conference - Keynote Speakers - paid special attention to the development of international cooperation of technical universities as a form of accelerating the transfer of innovations in mineral resources mining and processing.
\end{abstract}

\section{Introduction}

The problems of training global competences of mining engineers [1], resource universities' graduates international cooperation and working abroad [2], old industrial territories development [3], achievement of new ecologically-oriented goals [4] are the issues of discussions of Kuzbass scholars. So honorable Keynote Speakers initiated fruitful discussion on the Plenary Session, which was continued on Pannel Sections, devoted to perspective mining technologies, environment saving development of mining, innovative mining

\footnotetext{
*Corresponding author: tma.geolog@kuzstu.ru
} 
equipment, economic and social development of mining regions in general and Kuzbass (Western Siberia) in particular [5].

\section{Results and Discussions}

\subsection{The Keynote Speaker Prof. Michal Cehlár, Dean of Faculty of Mining, Ecology, Process Control and Geotechnologies of Technical University of Košice (Slovak Republic): Assessment process of concept for mining and its impact on the region}

In his Symposium Report Prof. Dean Michal Cehlár noted that the raw material policy of the Slovak republic reflects the all-society interest and is essential for the sustainable functioning of modern societies. Criticality of different metallic and mineral raw materials has gained attention in recent years. Consequently, the systematic evaluation of raw material criticality has been the subject of numerous studies in recent years.

Presenting their report Dean M. Cehlár initiated the discussion of the principles of evaluation of reconnaissance mineral resources, such as:

- reconnaissance mineral resources are estimated to the depths accessible to the current or future mining in accordance with current economic, mining, technical, technological and other conditions, while considering possible changes of these conditions in the future. The estimation is carried out in units of mass or tonnage in a limited reconnaissance area;

- the quantity of reconnaissance mineral resources is defined on the basis of expert estimations within the limits of large regions, basins or parts of deposit units;

- reconnaissance mineral resources are divided into Reconnaissance mineral resources P1 and P2, based on the positive evaluation of deposit indications and anomalies, and based on favourable stratigraphic, litologic, tectonic and paleographic assumptions.

Special interest of all participants was attracted to the position of mining studies and projects in the process of deposits evaluation which provides suitable information before verifying actual deposit (Fig. 1).

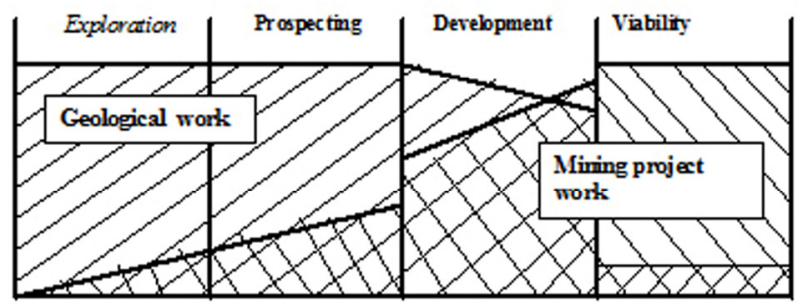

Fig. 1. Schematic display of consequences between geological and mining work in an industrial mineral deposit.

\subsection{The Keynote Speaker Prof. Dr. Juraj Janočko, Vice Dean of Faculty of Mining, Ecology, Process Control and Geotechnologies of Technical University of Košice (Slovak Republic): Faculty BERG and T.F. Gorbashev Kuzbass State Technical Uniretsity: Perspective ways of international cooperation}

Prof. Dr. Juraj Janočko described the place of Faculty of Mining, Ecology, Process Control and Geotechnologies of TUKE in the row of the word mineral resource universities. He presented F BERG TUKE as one of the most experienced mining Alma Mater in Europe, 
which historically refers to the Mining Academy in Banská Štiavnica, promoted to the academic level by Maria Theresa, the Empress of the Austria-Hungarian Monarchy, in 1762.

Now Faculty of Mining, Ecology, Process Control and Geotechnologies of Technical University of Košice provides sufficient base for innovative development of underground and open pit mining, surveying, raw material processing.

It was achieved by the development of strong research and educational system of $\mathrm{F}$ BERG that comprises both traditional mining (geology; mining; raw materials processing, environmental technologies, mining mechanization and automation, blasting, transport etc.) and innovative disciplines (deep drilling, GIS, geothermal exploration, 3D seismic interpretation, photogrammetry and remote sensing etc.).

Privileged place of F BERG TUKE in Slovakian system of education is proved by the high confidence of the Government. The Faculty of Mining, Ecology, Process Control and Geotechnologies acts as a strategic partner of the Ministry of Economy and Ministry of Environment of the Slovak Republic in the field of defining the new Slovak Raw Material Policy. The Faculty established and maintains a long-term cooperation with numerous mining and raw material processing companies, regional and state authorities dealing with mineral resources extraction issues

But for the development of F BERG TUKE and KuzSTU inter-universities cooperation the most important feature of Faculty of Mining, Ecology, Process Control and Geotechnologies is its membership in Slovak Raw Material Platform (Fig. 2).

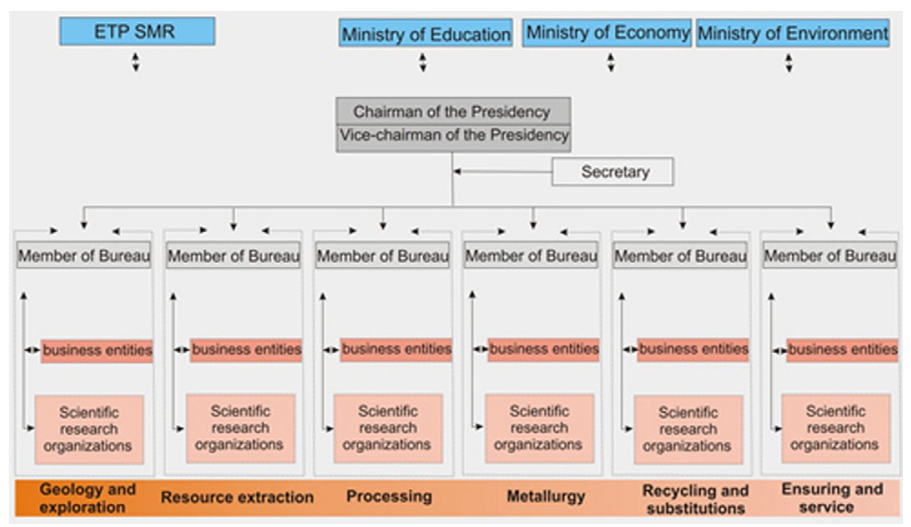

Fig. 2. F BERG - a member of Slovak Raw Material Platform

\subsection{The Keynote Speaker Assoc. Prof. Nuray Demirel, Mining Engineering Department of Middle East Technical University (Turkey): Mining Projects in Turkey and METU Mining Engineering Department}

In her Symposium report Lady Demirel presented one of the biggest and well-known technical universities of Asia - Middle East Technical University (Ankara, Turkey). Despite METU as a state university was founded not so long ago (November 15th 1956), it currently has 26,500 students, executes 43 undergraduate programs within 5 faculties, 5 Graduate Schools with 107 masters and 69 doctorate programs. 15 undergraduate programs and 3 graduate programs are offered in connection with METU Northern Cyprus Campus. The language of instruction at METU is English, and University has "School of Foreign Languages" which includes the English Preparatory Department and hosts over 1,700 international students from nearly 94 different countries studying toward myriad of academic degrees. 
METU initiated a long-term program to have all its engineering programs accredited by the United States Accreditation Board for Engineering and Technology (ABET). Each year, among the students taking the National University Entrance Examination, over $1 / 3$ of the 1000 applicants with the highest scores enters METU. Due to high demand towards METU, most of the departments accept only the top 1\% of approximately 1.5 million applicants taking the National University Entrance Examination. Over $40 \%$ of METU's students go on to graduate school. The campus area is 4500 hectares and the forest area is 3043 hectares, including Lake Eymir, which is about 20 kilometers from the centrum of Ankara.

UK-based Times Higher Education (THE) ranked METU the 12th in the "Asia University Rankings" for 2015 on June 10, 2015, the 85th among the world's best universities in October 2016. In 2012, 2013, 2014 The World Reputation Rankings, ODTÜ was also named among the top 100 most reputable universities in the world.

During the discussion all the participants of the Symposium were agree that the important key for METU and KuzSTU cooperation development is the steady growth of mineral resource extracting in Turkey for the last decade (Fig. 3).

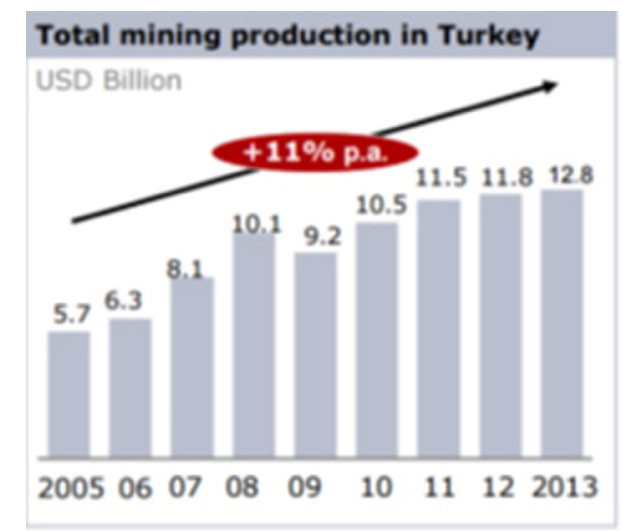

Fig. 3. Growth of mineral resource mining in Turkey.

\subsection{The Keynote Speaker Assoc. Prof. Seroni Anyona, Mining, Materials \& Petroleum Engineering Department of Jomo Kenyatta University of Agriculture \& Technology (Kenya): The ways of establishing cooperation between JKUAT and KuzSTU}

Mr. Anyona presented very interesting information about Jomo Kenyatta University, located more than 7,000 km from Kuzbass. Participants were pleased to know that JKUAT staff counts more than 2,250 people among which 761 are academic and 1489 nonacademic. Academic structure of Jomo Kenyatta University of Agriculture \& Technology includes:

1. College of Engineering and Technology (CoETEC).

2. College of Pure and Applied Sciences (CoPAS).

3. Faculty of Agriculture.

4. School of Architecture and Building Sciences (SABS).

5. College of Human Resource Development (COHRED).

6. College of Health Sciences (COHES).

7. Seven research centers: Institute of Biotechnology Research (IBR), Institute of Energy and Environmental Technology (IEET), Sustainable Materials Research and Technology Center (SMARTEC), Water Resource and Research Center (WARREC), Center for Urban Design and Planning. 
8. Six Production and Innovation Centers. The students' body of JKUAT accounts for 35,000 students being taught 234 programmes.

Mr. Anyona demonstrated map of University linkages, including KuzSTU (Fig. 4).

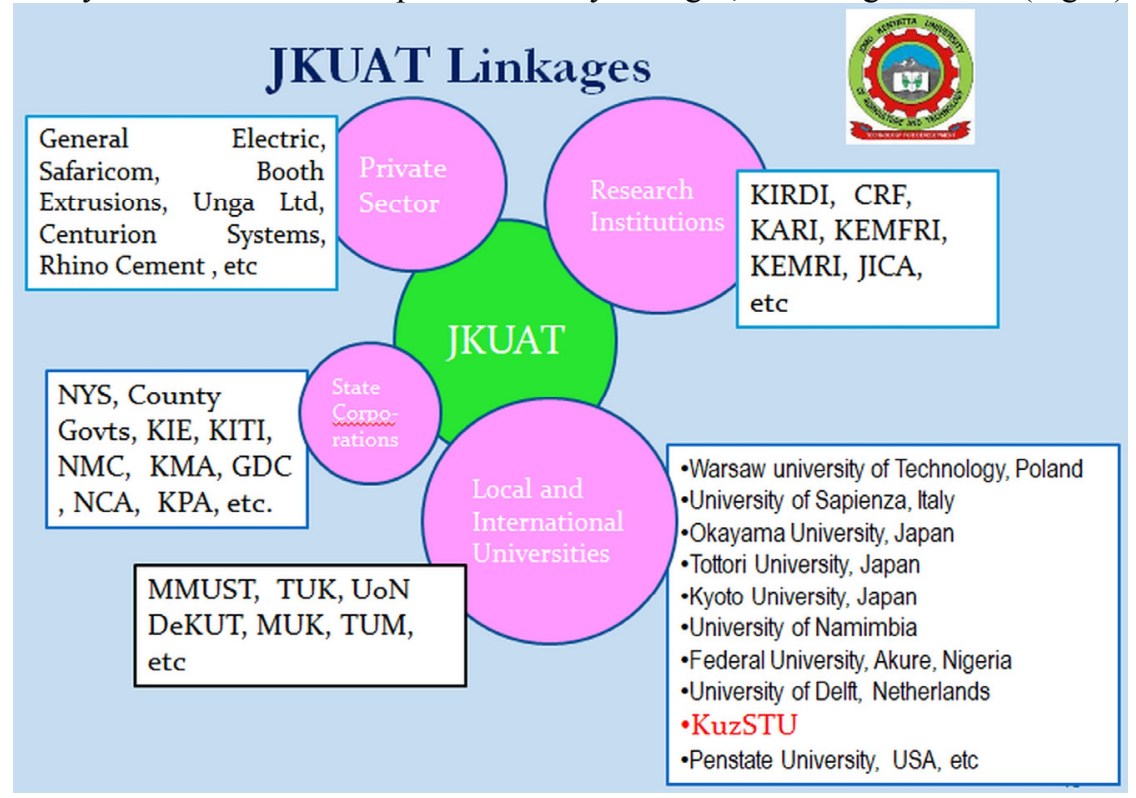

Fig 4. Map of inter-universities connections of JKUAT

\subsection{The Keynote Speaker Dr.-Ing. Prof. Stefan Vöth, Technische Fachhochschule Georg Agricola, Bochum (Germany): Safety is a priority for innovations}

Prof. Vöth introduced TFH Georg Agricola to the participants and visitors of Symposium as a private, state-recognized university in Bochum, founded in 1816 as a mountain school. After years it developed into a modern European university, with nearly 2300 students enrolled at the winter semester 2016/2017. $88 \%$ of them are male, $9 \%$ are students with a different nationality and 49\% are graduates. Since 1995 this Technische Fachhochschule has received the name of the universal scholar Georgius Agricola, who was honored as a pioneer of mining and mineralogy.

Pof. Stefan Vöth told to the listeners that mining has an old tradition in the Ruhr area. In order to train the management staff for mining, a special school - Bergbauschule - was established 1816, and its goal was to provide people with a broad basic technical knowledge. The graduates of the Bochum miming school deserved at that time a good reputation that came ahead. In 1864, the Westfälische Berggewerkschaftskasse (WBK), which remained until 1990, became the bearer of the school through the merger of the Märkische and the Essen-Werden mining cooperative. In addition to the training of the experts, the Bergschule had to cope with further tasks, such as carrying out scientific examinations and making seam maps. Now TFH Georg Agricola specializes in mining machine technology and electrical engineering, surveying, mineral resource process engineering.

Substantial part of Prof. Vöth's report was devoted to Multifunctional Testing Rig for Machinery Safety Equipment. The attention of KuzsTU members - mining machinery engineers - attracted the drivetrain of testing rig (fig. 5). 


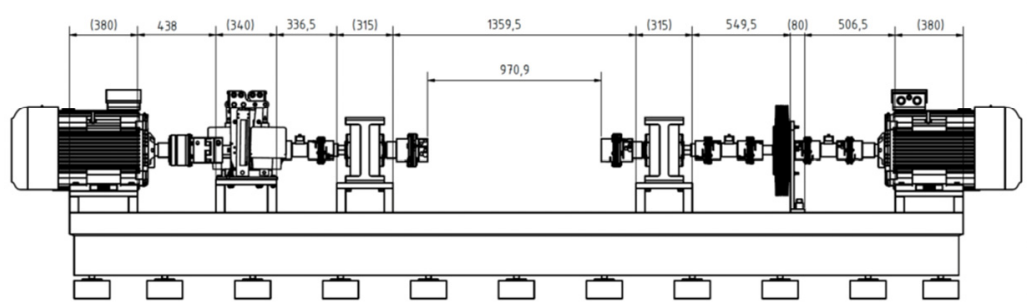

Fig. 5. Drivetrain of testing rig for Machinery Safety Equipment.

\subsection{The Keynote Speakers Prof. Dr. Sergey Zhironkin and Prof. Maxim Tyulenev, Department of open pit mining, T.F. Gorbachev Kuzbass State Technical University (Russian Federation)}

Prof. Zhironkin and Prof. Tyulenev reported about the man in whose honor and memory the First International Innovative Mining Symposium was named after - Dr. Prof. Vladimir Pronoza (1939-2015). The most famous books of Prof. Pronoza are the following: "Scientific bases of open pit mining (direct dumping method)", Kemerovo, 1984; Fundamental work "Typical technological schemes at coal open pits", Moscow, 1982; "Development of coal-bearing zones of quarry fields by excavator-and-transport complex", Kemerovo, 2010; "Open pit mining technology for complex-structured coal deposits development”, Kemerovo, 2010.

Prof. Sergey Zhironkin described the leading role of Western Siberian mining cluster in Russian coal industry (Fig. 6).

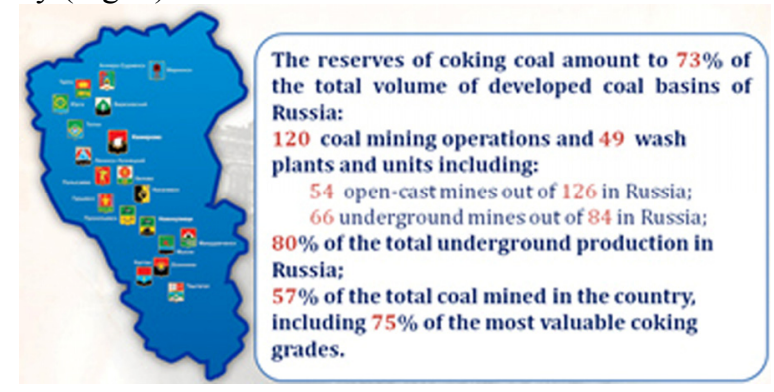

Fig. 6. Mining engineers - the future of Coal Regions Kuzbass.

Prof. Maxim Tyulenev emphasized that the competitive advantage of KuzSTU on higher education market is a unique platform for establishing business and scientific-technical cooperation with leading enterprises of Kuzbass. A relatively small area of the Kemerovo region has more than 5,500 industrial enterprises, in which the majority of specialists and managers are KuzSTU graduates who maintain a close relationship with their Alma Mater. Moreover, currently KuzSTU has 76 strategic agreements with enterprises of the Kemerovo region. 


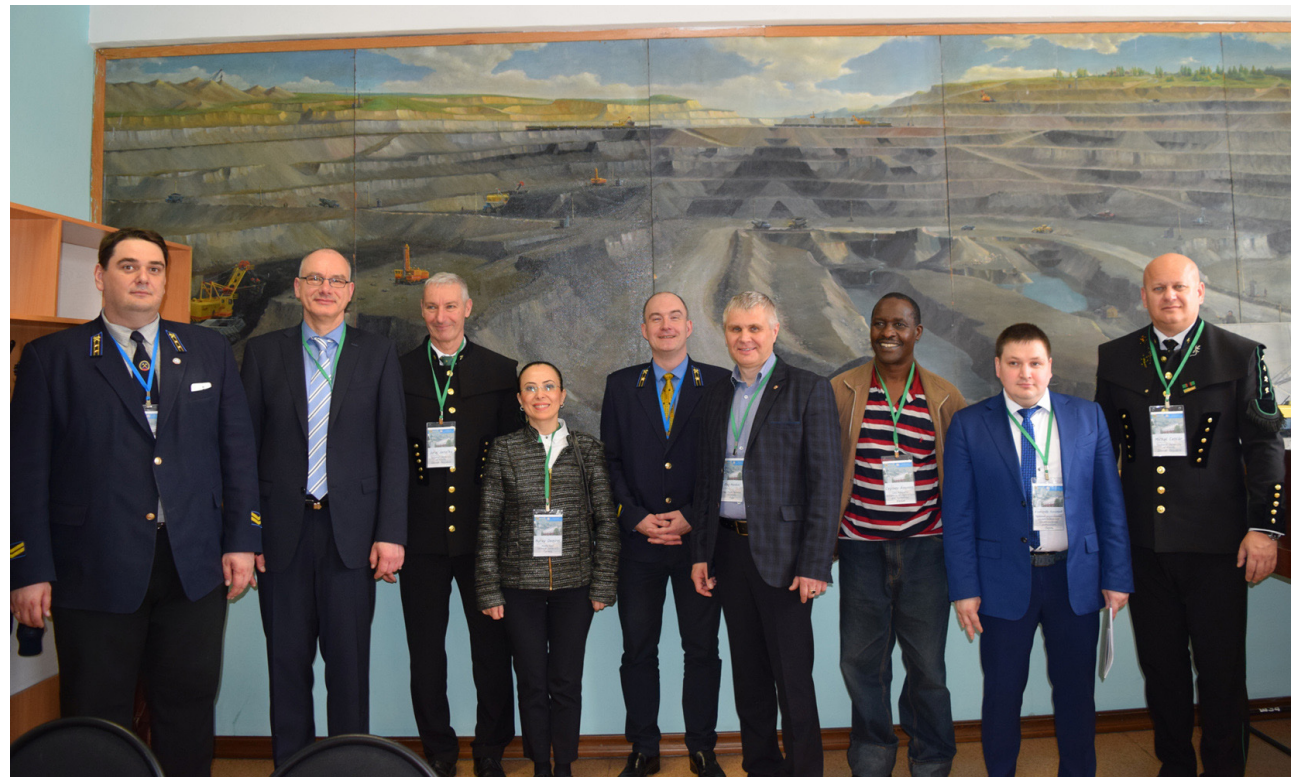

Fig 7. The Keynote Speakers of the First International Innovative Mining Symposium (in memory of Prof. Vladimir Pronoza) at T.F. Gorbachev Kuzbass State Technical University. From the left to the right: Prof. Maxim Tyulenev, Dr.-Ing. Prof. Stefan Vöth, Prof. Dr. Juraj Janočko, Assoc. Prof. Nuray Demirel, Prof. Dr. Sergey Zhironkin, Prof. Dr. Oleg Misnikov (guest), Assoc. Prof. Seroni Anyona, Assoc. Prof. Alexandr Nikolaev (guest), Prof. Dean Michal Cehlár (photo courtesy of S. Zhironkin).

\section{Conclusion}

At the end of the First International Innovative Mining Symposium and following its results there was signed a Communique of International Cooperation of Universities.

\section{Acknowledgement}

We express their great gratitude to EDP Sciences and Isaline Augusto personally. Publishing the Symposium Papers with E3S Web of Conferences appeared to be beyond our expectation. We also would like to extend thanks to the members of EDP Sciences Isabelle Houlbert and Catherine Nissen for their utmost attitude to our issues and questions.

\section{References}

1. A.A. Khoreshok, S.A. Zhironkin, M.A. Tyulenev, G.A. Barysheva, V.Y. Blumenstein, M.C. Hellmer, S.V. Potyagailov, IOP Conf. Ser.: Mater. Sci. Eng., 142: 1, 012122 (2016)

2. I. Pevneva, O. Gavrishina, A. Rolgayzer, M. Agienko, A. Myaskov, E3S Web of Conf., 15, 04016 (2017)

3. V. Trifonov, O. Loyko, D. Nesteruk, S. Zhironkin, E. Strekovtsova, AIP Conf. Proceed., 1800, 050009 (2017)

4. A. Krechetov, E3S Web Conf. 15, 00001 (2017)

5. M.A. Gasanov, K.A. Kolotov, K.A. Demidenko, E.A. Podgornaya, O.V. Kadnikova, IOP Conf. Ser.: Earth Environ. Sci., 50:1, 012025 (2017) 
